\title{
Maximum Spanning Tree Graph Model: National Examination Data Analysis of Junior High School in Lampung Province
}

\author{
Sugama Maskar \\ Departmen of Mathematics Education, Faculty of Arts and Education, Universitas Teknokrat Indonesia, \\ Jl. ZA. Pagar Alam No.9 -11, Labuhan Ratu, Kota Bandar Lampung, Indonesia. \\ Email: sugama_maskar@teknokrat.ac.id
}

\begin{abstract}
The purpose of this study is to determine the tendencies of learning in Lampung Province especially at junior high school level. Subjects of this study are all result of national examination data for junior high school in 2017 and 2018 in Lampung Province. The method of this study using model analysis of maximum spanning tree (MST) graph assisted by descriptive and inferential statistics technique. The data obtained are analysed using descriptive statistical analysis to find out the basic information of the data and inferential statistical analysis to get the value of coefficient correlation. Then, the MST graph is formed using Kruskal's algorithm by interpreting the vertices as a subject and the edges as the value of coefficient correlation. The subject that have the closest relationship to any subject is a graph vertex with the greatest degree. Based on the MST graph model, the result of this study shows that the subject which has closest relationship with another subject is Science in 2017, while in 2018 are English and Mathematics. Based on these result and relevant research, the conclusion shows that Science and Mathematics to be the centre for the national examination of junior high school in 2017 and 2018 in Lampung Province.
\end{abstract}

Keywords: National Examination, MST Graph, Lampung.

\section{INTRODUCTION}

One of the evaluations of learning from the Indonesian government is national examination. Based on the official the Ministry of Education and Culture website on mentioned that the education assessments center discharge annual analysis of the national examination's results. Those results are set as the basis for improving the quality of education. But the question is, how far have the national examination analysis done? National examination's analysis is so far oriented on mapping results like determining the lowest and highest nationally or determining which areas have the highest and lowest average.

The author believes that the national examination data needs to be optimized, since the data is plentiful and will be useful if it is analyzed thoroughly. Based on data from www.unbk.kemendikbud.go.id (2017) [1], the school who already took in the national test of computer based in 2015, 2016, and 2017 respectively 555, 4382, and 30.557. That number does not include the schools that have taken national examination on paper. According to www.jpp.go.id (2018) [2] that by 2018 the number of schools that took the national examination of computer based into 69.113 with a predicted number of participants 6.291 .323 students. Based on this, over 11 million national examination data has been estimated to be collected from 2015 to 2018 as early as elementary school until senior high school. The amount of data is huge to evaluate education in Indonesia for the better.

According to the information, the authors are interested in thoroughly analyzing the national examination value data for the student's learning tendencies in general area. In order to see this tendency, the authors use Spanning Tree Graph by interpreting the vertices as a subject and the edges of graph as the value of coefficient correlation. The goal is to see the inclination of the majority of subjects affect other subjects and it will become the basis for authors to analyze the learning and thinking patterns of Indonesian students. At the end, it can be as one of the basic competencies that teacher can be used to improve student learning outcomes significantly.

\section{MATERIALS AND METHODS}

\section{Study area and procedures}

Method of this study uses model analysis of maximum spanning tree (MST) graph assisted by descriptive and inferential statistics technique by analyzing the junior high school national examination in Lampung Province academic year 2016-2017 and 2017-2018 with the following stages (figure 1).

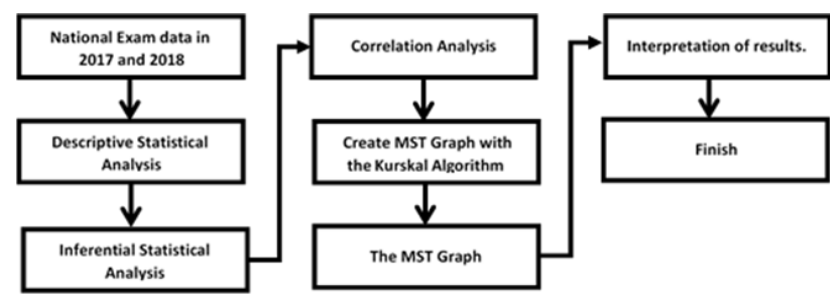

Figure 1. Flowchart of Research Design. 
The study start from collecting data in the Junior High School national examination grades for the academic year 2016-2017 and 2017-2018 in Lampung Province, the data is obtained from the Lampung provincial agency and site www.puspendik.kemendikbud.go.id which consists of four national examination subjects there are Mathematics, Science, Bahasa Indonesia, and English. The data obtained are analyzed using descriptive statistical analysis techniques to find out the initial description of the data. Then inferential statistical analysis is used to infer the previous analysis. In inferential analysis also obtained correlation coefficient values between subjects with the Spearman or Pearson Correlation Test, depending on the normality of each data group.

\section{Data analysis}

Based on the value of the correlation coefficient for each subject then an initial graph is weighted graph with the vertices as the subject and the edges on the graph as the value of correlation coefficient for the two subjects as in the following figure:

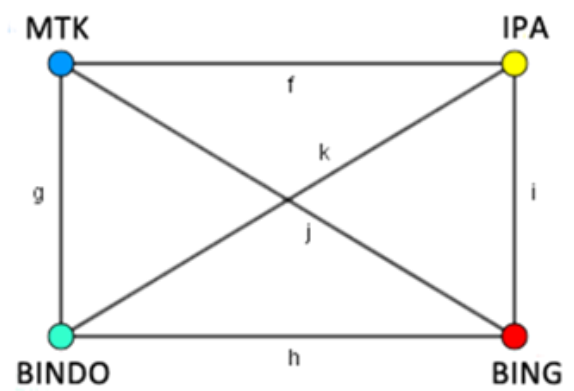

Figure 2. The Initial Graph For Each Subject In The Junior High School National Examination

The values of $\mathrm{f}, \mathrm{g}, \mathrm{h}, \mathrm{i}, \mathrm{j}$ and $\mathrm{k}$ are the weight of the graph consisting of correlation coefficients for each subject. Based on the initial graph, a Maximum Spanning Tree (MST) graph is formed using the Kruskal's Algorithm from the largest to the smallest coefficient correlation based on the following provisions (Sugiyono, 2015) [3]:

Table 1. Level of Relationship Coefficient Correlation.

\begin{tabular}{ll}
\hline Coefficient Interval & Correlation Level \\
\hline $0.00-0.1999$ & Very week \\
$0.20-0.399$ & Week \\
$0.40-0.599$ & Moderat \\
$0.60-0.799$ & Strong \\
$0.80-1.00$ & Very strong \\
\hline
\end{tabular}

The Maximum Spanning Tree is a graph model that is suitable to see the influence or relationship for each vertex. The Maximum Spanning Tree graph does not have a cycle, so to see a vertex that has the most influence on another vertex on the tree graph can be done by determining the vertex that has the most branches (Rosen, 2013) [4].

Based on Wattimena and Lawalata (2013) [5], with a slight modification, the formation of the Maximum Spanning Tree graph with the Kruskal's Algorithm is as follows:

1. The weight edge of the graph $G$ is sorted from the largest weight to the smallest

2. Select the edge $u, v$ which has the maximum weight that does not form the cycle. Add $u, v$ into $T$.

3. Repeat step 2 until the Maximum Spanning Tree is formed, that is, when the side in the tree stretches $T$. number $n-1$ ( $n$ is the number of vertices in the graph).

Through the MST graph, the subjects that became the center are conducted at the Lampung Province Junior High School. The authors will find subject centers for several groups of data, namely the junior high school national examination level in Lampung Province for the academic year 2016-2017 and 2017-2018.

Based on the MST graph, the authors carried out further analysis by looking at the extent of the influence of Mathematics and Science on other subjects? By using relevant theory, the authors try to compile temporary answers about the fundamental things that affect Mathematics and Science subjects against other subjects if the results of the study show that Mathematics or Science becomes the center of the MST Graph in this study. Furthermore, the basic assumption can be used as a reference for further research.

\section{RESULTS AND DISCUSSION}

The following are the results of Junior High School National Examination data of Lampung Province for 2017 and 2018.

Table 2. Numerical Essence of Lampung Province Junior High School Data 2017 and 2018.

\begin{tabular}{lll}
\hline & $\mathbf{2 0 1 7}$ & $\mathbf{2 0 1 8}$ \\
\hline Minimum & 25,63 & 21,00 \\
\hline Maximum & 93,36 & 86,03 \\
\hline Mean & 49,40 & 45,01 \\
\hline Standards Deviation & 12,67 & 12,57 \\
\hline
\end{tabular}

Based on table 2, it can be seen that there are schools that have an average score of 93,36 in 2017 and 86,03 in 2018. However, there are also schools where the average score is still low at 25,63 in 2017 and 21,18 in 2018. It shows that there is a gap in Junior High School education in Lampung Province. When viewed from the average value, the whole is also still low, which is 49,40 in 2017 and has decreased in 2018, which is 45,01. 
Before choosing the type of correlation, it is necessary to analyze the relationship between two variables. One of the tools that can describe the relationship between variables and collinear is scatterplots. The following is presented in the scatterplot of Junior High School Lampung Province 2017 and 2018 with the help of SPSS.

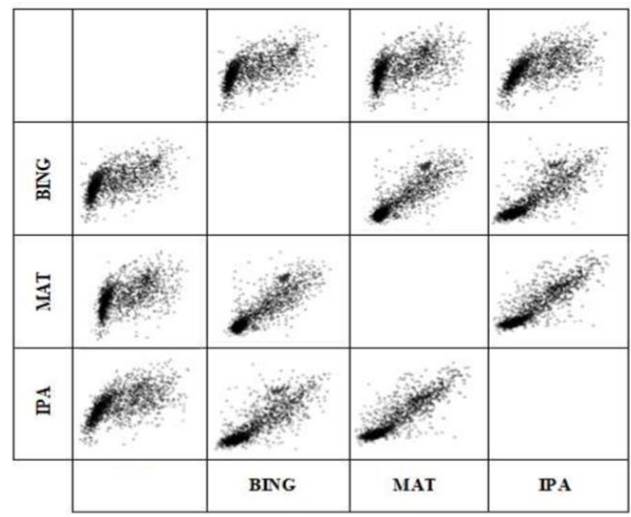

Figure 3. Scatterplot of Junior High School National Examination Values of Lampung Province in 2017.

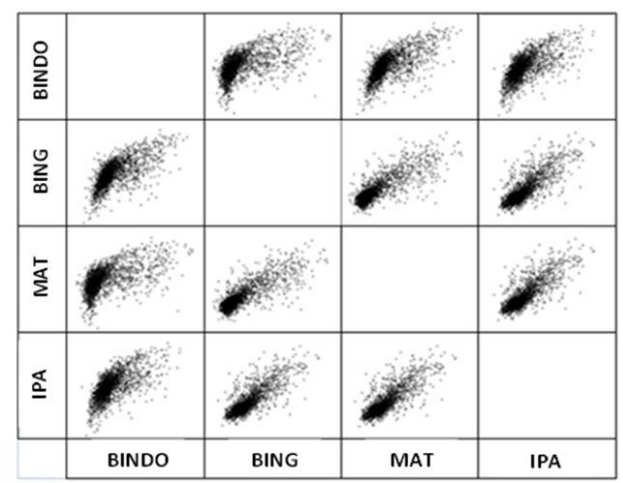

Figure 4. Scatterplot of Junior High School National Examination Values of Lampung Province in 2018.

Moreover, in the Junior High School National Examination in 2018 which has a linear relationship, are English-Science, Mathematics-Science, and EnglishMathematics. While the other data does not show a linear relationship. To prove this suspicion, the MST graph is formed by interpreting the vertices as subjects and the edges as coefficient correlation between subjects.

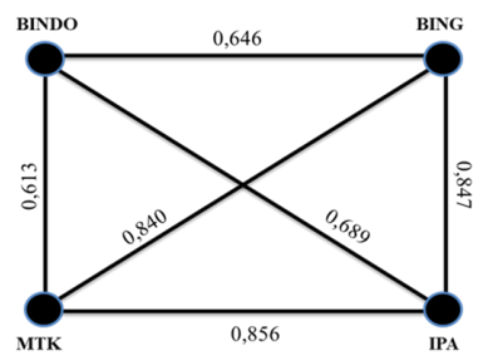

Figure 5. Initial Graph of Lampung Province Junior High School National Examination Results 2017.
Figure 5 is the initial graph of the Junior High School National Examination of Lampung Province in 2017 which is formed by connecting all National Examination subjects and then obtaining the edges of the graph given the Spearman coefficient correlation weight.

Table 3. List the sequence of coefficient correlation values between subjects.

\begin{tabular}{ll}
\hline Coefficient Correlation & Variable \\
\hline 0,856 & MAT-IPA \\
\hline 0,847 & BING-IPA \\
\hline 0,840 & BING-MTK \\
\hline 0,689 & BINDO-IPA \\
\hline 0,646 & BINDO-BING \\
\hline 0,613 & BINDO-MAT \\
\hline
\end{tabular}

The following are the steps to form the Maximum Spanning Tree graph from the results of the Junior High School National Examination of Lampung Province in 2017 using the Kruskal's Algorithm.

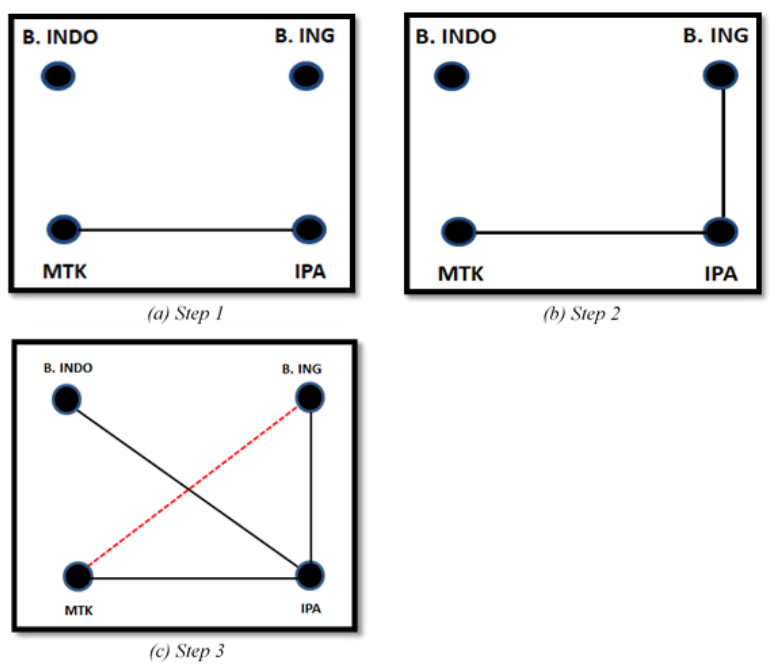

Figure 6. Steps to obtain the MST graph of Junior High School National Examination in Lampung Province 2017.

Description of Figure 6:

(a) Select the correlation that have the closest relationship are Mathematics and Science with a coefficient correlation of 0,856 .

(b) The second edge are English and Science with a coefficient correlation of 0,847 .

(c) The last edge is English and Mathematics, but this edge cannot be chosen because MTK-IPA-BING route is cycle. Therefore, the last edge is Bahasa Indonesia and Science with a coefficient correlation of 0,689

The following are the steps to form the Maximum Spanning Tree graph from the results of the Junior High School National Examination of Lampung Province in 2018 using the Kruskal's Algorithm. 

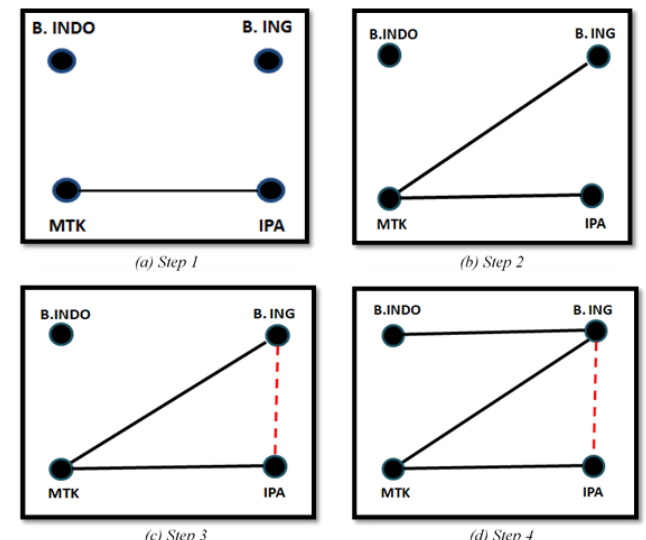

Figure 7. Steps to obtain the MST graph of Junior High School National Examination in Lampung Province 2018.

Description of Figure 7:

(a) Select the correlation that have the closest relationship are Mathematics and Science with a coefficient correlation of 0,785 .

(b) The addition of the second edge is Mathematics and English with a coefficient correlation of 0,756 .

(c) The addition of the last edge is English and Science with a coefficient correlation of 0,756 , but this side cannot be chosen because it forms a cycle.

(d) Next, English and Bahasa Indonesia are added with a coefficient correlation of 0,696.

(e) Based on the previous Kruskal's Algorithm, a Maximum Spanning Tree graph of the Junior High School National Examination data of Lampung Province in 2017 and 2018 is formed, respectively, can be seen in Figure 8 and Figure 9.

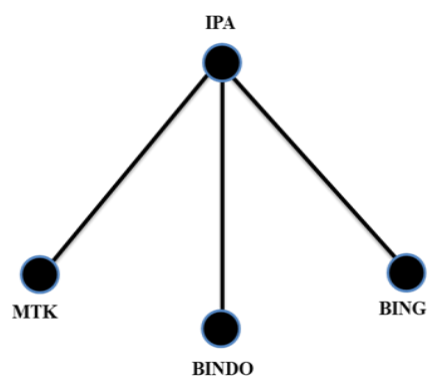

Figure 8. Maximum Spanning Tree Graph of Junior High School National Examination Lampung Province in 2017.

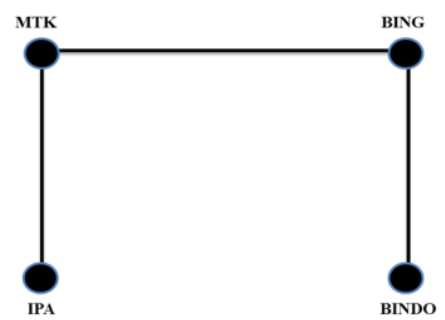

Figure 9. Maximum Spanning Tree Graph of Junior High School National Examination Lampung Province in 2018.

\section{CONCLUSION}

Based on the analysis that has been done, it can be concluded that there are three subjects that affect other subjects in the Junior High School National Examination Lampung Province 2016-2017 and 2017-2018 are Mathematics, Science, and English. This is accordance with the previous research conducted by Nurviana (2016) [6] and Maskar, et al. (2017) [7] which the subject centres are Science and Mathematics for the National Examination of one school in Aceh and the National Examination Senior High School Science Program in Lampung Province 2017. As a result, Science and Mathematics competency must be owned by students to improve learning outcomes in other subjects.

Interestingly, this research found English to be one of the subjects that influenced other subjects in the Junior High School National Examination of Lampung Province in 2018. This could be the basis for further research.

\section{ACKNOWLEDGEMENTS}

Thanks to Universitas Teknokrat Indonesia (UTI) for the support so that this research can be carried out well and can be published, I hope this research can be useful for education in Lampung Province.

\section{REFERENCES}

https://unbk.kemdikbud.go.id/tentang. January 6th 2019.

Lawalata, S. \& Wattimena, A.Z. 2013. Aplikasi Algoritma Kruskal dalam Pengoptimalan Panjang Pipa. Jurnal Ilmu Matematika dan Terapan, 7(2), 13-18.

Maskar, S., Anderha, R.R., dan Andriyanto. 2018. Evaluasi Nilai UN SMA/MA IPA Provinsi Lampung dengan Graf Maximum Spanning Tree. Seminar Nasional Metode Kuantitatif II. November 19-20th 2018, Bandarlampung, Indonesia. 12-19.

Nuraini, R. .2018. Melonjak Tajam, Jumlah Sekolah dan Siswa yang Ikut UNBK 2018 https://jpp.go.id/teknologi/pendidikan/319581-melonjaktajamjumlah-sekolah-dan-siswa-yang-ikut-unbk-2018. January 6th 2019.

Nurviana. 2016. Mengukur Mutu Pendidikan Berdasarkan Nilai Ujian Nasional Program IPA SMAN 3 Putra Bangsa Lhoksukon Aceh Utara Tahun 2014 Dan 2015. Tesis. Institut Teknologi Bandung.

Rosen, Kenneth H. 2013. Discrete Mathematics and its Applications. 7th edition. McGraw-Hill: New York.

Sugiyono. 2015. Statistika untuk Penelitian. Edisi ke-6. Alfabeta, Bandung. 